๑ Entomologica Fennica. 18 April 1997

\title{
Forestry effects on a boreal ground beetle community in spring: Selective logging and clear-cutting compared
}

\author{
Ola Atlegrim, Kjell Sjöberg \& John P. Ball
}

\begin{abstract}
Atlegrim, O., Sjöberg, K. \& Ball, J. P. 1997: Forestry effects on a boreal ground beetle community in spring: Selective logging and clear-cutting compared. - Entomol. Fennica 8: 19-26.
\end{abstract}

To compare the effects of two tree harvesting methods (clear-cutting and single tree selection felling), spring-occurring ground beetles (Carabidae) were studied by pitfall trapping in northern Sweden. Species abundance, total abundance and Hill's diversity indices were used to compare the ground beetle community in clear-cuts to selectively-logged and to uncut control forests. In addition, to highlight the importance of site replication when evaluating a spatially-variable ecosystem like the boreal forest, we consider how our conclusions might have differed with and without site replication. Results from the two analyses differed considerably, highlighting the importance of site replication in studies of forestry effects in order to increase confidence in the conclusions. Overall, no significant harvest effects were found on the ground beetle community except for a significantly higher abundance of the open habitat species $P$. assimilis in clear-cuts than in uncut control forests. Our results thus do not support suggestions of an increase in diversity following clear-cutting, but are consistent with previous findings regarding increased abundances of open habitat species and no changes in abundance of forest generalists in clear-cuts. In general, the carabid community in the selection loggings resembled that in the uncut control forest, indicating a low effect of this harvesting method. Based on our analysis, we suggest that future studies of forestry impacts on invertebrates attempt to increase the number of sites evaluated rather than increase the number of samples from a given area.

Ola Atlegrim, Kjell Sjöberg \& John P. Ball, Dept. of Animal Ecology, Swedish University of Agricultural Sciences, S-901 83 Umeå, Sweden; e-mail: Ola.Atlegrim@szooek.slu.se

Received 6 July 1994, accepted 21 November 1995

\section{Introduction}

The boreal coniferous forest is quite variable and has a high habitat diversity (Cajander 1949, Scudder 1979, Haila \& Järvinen 1990). Formerly, this diversity was mainly maintained by fire (Zackrisson 1977, Bonan \& Shugart 1989, Clark 1990, Loope 1991). Today in Sweden, the clear-cutting method is the dominant silvicultural practice for both timber and pulp production. The clear-cutting of forests, i.e. removal of the whole tree layer, has replaced fire as the main disturbance (HämetAhti 1983, Tolonen 1983, Hansen et al. 1991, Punttila et al. 1991). Clear-cutting can have profound effects on the invertebrate fauna (e.g. Heliövaara \& Väisänen 1984). Several invertebrate spe- 
cies do not easily adapt to this new type of disturbance, and this has resulted in an extinction threat for some of them (e.g. Ehnström \& Walden 1986). Furthermore, due to the variety of habitat types in the boreal coniferous forest, clear-cutting may have varying effects on forest invertebrate species composition and diversity. The increasing awareness of the negative effects of clear-cutting has led to a growing interest in other forestry methods.

One of the few well-developed alternative silvicultural practices is the single tree selection felling method (Daniel et al. 1979; hereafter called "selective logging"). The selective logging method can be applied in uneven, multi-layered forest stands. In this method, single trees are selected for harvest, and the trees to be harvested are evenly distributed among the tree age classes with respect to harvested tree volume. The stand is naturally regenerated by the growth of young trees. Thus, with the selective logging method, an intact but thinned tree layer will be left after harvesting which may better preserve the original forest conditions than the clear-cutting method and may therefore have more moderate effects on the forest fauna and flora than clear-cutting.

Ground beetles (Carabidae) are indicators of environmental conditions and changes therein (Thiele 1977, Jarosik 1983, Tietze 1987, Eyre \& Luff 1990, Niemelä et al. 1993ab). Carabids have also been commonly used to study effects of clearcutting (e.g. Sustek 1981, Lenski 1982, Jennings et al. 1986, Niemelä et al. 1993ab). Because carabid beetles are diverse and abundant, taxonomically well known (Lindroth 1949, 1985, 1986), and seem to be sensitive to habitat changes, they are particularly suitable organisms for these types of studies (Refseth 1980, Niemelä 1990, Niemelä et al. 1988, 1990a, 1992, Luff 1990, Rushton et al. 1990). However, most previous studies of forestry effects on the carabid community have compared clear-cutting with control (unlogged) sites and, to our knowledge, no studies on the effects of selective logging exist. The growing discussion of the need to investigate alternative forestry practices (like selective logging) that are more in line with current strategies to conserve biodiversity makes such research very timely.

The first aim of the present study was to compare uncut control stands, clear-cuts and areas sub- jected to selective logging. The study comprises the first years after harvest and the oldest cuttings were four years old. Because only about $30 \%$ of the tree layer was removed with the selective logging method, this method was expected to have less dramatic effects than the clear-cutting method on the ground-dwelling invertebrate community. Thus, in this study, we determine if the carabid beetle community in the selectively-logged areas resembles that in the uncut control forests more than that in the clear-cut forests.

Secondly, some previous studies on ground beetle communities have compared a single pair of control and logged sites - given the practical difficulties in doing experimental logging, this lack of site replication is to be expected. However, in the future, there might be greater opportunities for researchers to employ study designs with more site replication because of the growing interest by many forestry companies in co-operating with ecological research. Nevertheless, there will always be a trade-off between allocating the maximum possible sampling effort to either few sites (with greater replication at each site), or to a greater number of sites (with less replication at any given site). Thus, a second aim of this study was to examine this trade-off by considering how our conclusions might have differed, had we (like some previous studies) been unable to replicate our experimentally-logged forests.

\section{Methods}

\subsection{Study area}

The study was conducted in the Vilhelmina region in the mountain range near lake Bielite $\left(64^{\circ} 55^{\prime} \mathrm{N}, 15^{\circ} 30 \mathrm{E}\right)$, which is located in Lapland, Sweden. The lake is $487 \mathrm{~m}$ above sea level and in an area where the coniferous tree line is about $700 \mathrm{~m}$ above sea level. The area belongs to the northern boreal region (Ahti et al. 1968). The ground consists of eokambrian sandstone and the soil varies from sand/fine sand to gravel till. The mean precipitation is about $750 \mathrm{~mm}$ per year, and the mean length of the vegetation period is about 120 days (Ångström 1974). Snow normally covers the ground from the beginning of October until the end of May (about 200 days). The entire region had been logged with diameter limit cutting (i.e. cuttings restricted to large, old coniferous trees with wide diameters) once or twice.

Three mature forests were used for the study. Each forest was sub-divided into three stands of about 20 ha each. 
Within each forest, the stands were randomly selected: one stand was left uncut as a control, another was harvested with the clear-cutting method, and a third was cut with the selective logging method. In selective loggings $30 \%$ of the tree numbers and $45-50 \%$ of the tree volume were removed. The cutting was distributed over all age classes. In keeping with conventional practices, the whole tree layer was removed in the clear-cutting areas.

\subsection{Sampling and analyses}

Within each stand (treatment) ten pitfall traps were randomly located. Plastic jars, $7 \mathrm{~cm}$ high and $7 \mathrm{~cm}$ in diameter were half filled with a 1:1 mixture of ethylene glycol and water, and with a surface-tension reducer added (dishwashing detergent). The traps were in operation from June 13 to July 2, 1992.

In addition to analysis of the differences between treatments with respect to abundance of different species and total abundance, differences in carabid diversity was also tested. Hill's three diversity indices (Ludwig \& Reynolds 1988) were used to calculate diversity. The first index, Hill's N0 index, is the total number of species. The second index, Hill's N1 index, represents a measure of the number of abundant species while the third index, Hill's N2 index, is the number of very abundant species. Thus, low values of N1 and N2 indices indicate that few species dominate and that the total abundance is more unevenly distributed among the species (Ludwig \& Reynolds 1988).

Non-parametric statistical analyses were used because they are robust with small sample sizes. The data were analysed in two ways. First, to duplicate a typical nonreplicated study, we analysed each forest area separately with the Kruskal-Wallis One-Way analysis of variance. Second, to contrast this against a study with the same sampling effort but with site replication, we used the Friedman's test (a non-parametric analog of a two factor analysis of variance). In case of a significant effect of treatment in the Friedman's test, differences between treatments were then tested by means of a non-parametric multiple comparison analysis similar to the Tukey procedure, but applicable to ranked data in a randomized block design (Zar 1984: 230-231).

\section{Results}

Although ground beetles are generally not particularly numerous in the mountain region of Sweden (Lundberg 1986), we caught a total of 179 individual beetles representing nine species of eight taxa. Leistus ferrugineus, Patrobus assimilis and Calathus micropterus dominated. Three species (Carabus violaceus, Loricera pilicornis and Bembidion grapeii) occurred in rather low numbers and could not be included when testing differences in individual species abundances between the three treatments (control, clear-cut or selectively-logged). All species, however, were included in the analysis of total abundance and in the calculation of diversity indices.

The results of both the unreplicated design (Kruskal-Wallis test) and the replicated design (Friedman's test) are shown in Table 1. The three different forests showed a considerable variation in the effects of harvest method. No significant effects of tree harvest were found in Forest 1 (Table 1). In Forest 2 both Hill's N1 and N2 indices were significantly affected by treatment (Table 1, Fig. 2). Significant effects of treatment on the two most abundant species $P$. assimilis and $C$. micropterus, and the number of species were found in Forest 3 (Table 1, Fig. 1). It is noteworthy that the analysis of any of the three individual forests would not have led to the same conclusions regarding forestry impacts on the invertebrate community as the same data in the replicated analysis.

Of course the best general assessment of forestry effects comes from the replicated analysis in which variation between sites is considered. Turning now to this replicated analysis, we find that there was no significant overall effect of treatment (control, clear-cut or selectively-logged) on the abundance of two of the dominant species C. micropterus and L. ferrugineus (although the highest abundances were found in clear-cuttings in two of the three studied forest areas, Fig. 1). Harvest method had, however, a significant effect on the third dominant species, $P$. assimilis, which was significantly more abundant in clearcuttings than in uncut control forest areas (Fig. 1, $p=0.05)$. There was no significant effect of treatment on the overall abundance of carabids (Table 1 , $\mathrm{p}=0.558$ ), although abundance was higher on clear-cuttings in two of the three forests (Fig. 1). The number of species and Hill's N1 index (Fig. 2) was higher in clear-cuttings in Forests 2 and 3, but once again this was not a significant overall effect of treatment (Table 1, p > 0.264). The Hill's N2 index (i.e. the number of very abundant species), tended to be highest in clear-cuttings followed by selective logging and then uncut control forests (Fig. 2, p = 0.097). 

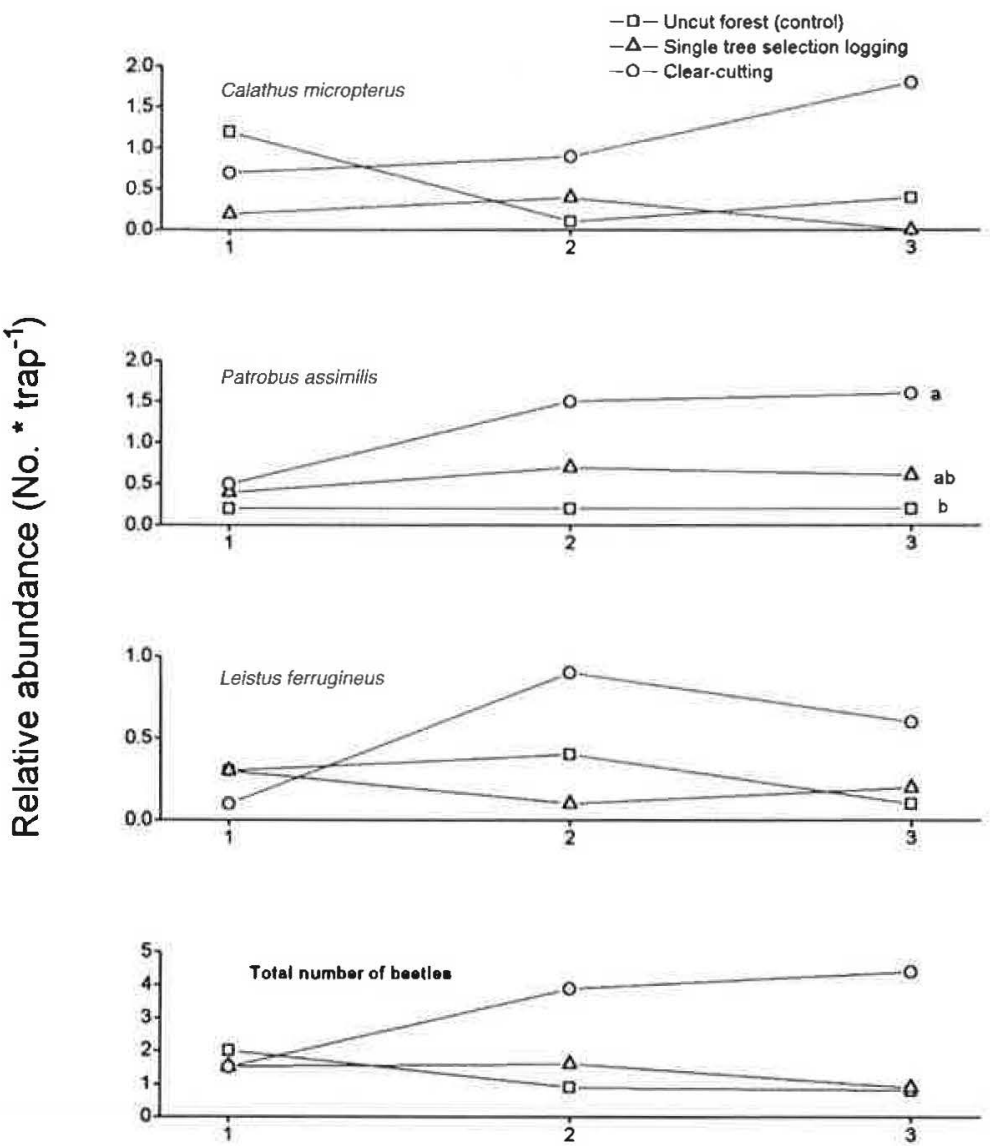

Fig. 1. The relative abundance of the three dominant carabid species and total abundance of carabids in each treatment (uncut forest (control), clear-cutting and selective logging) within each forest. Each value is based on a mean of ten traps. For Patrobus assimilis significant differences between treatments are indicated by different letters at the right end of

Forest number the figure.

Table 1. Effects of treatment (i.e. clear-cutting, selective logging and uncut control forest) on abundance and diversity of carabid beetles using non-parametric analyses with and without replicated experimental design. In the unreplicated experimental design each forest area was analyzed separately using the ten traps from each treatment. The replicated analysis was based on the mean values of ten traps in each treatment within each of three forest blocks (areas). $\mathrm{N}=$ number of samples.

\begin{tabular}{|c|c|c|c|c|c|c|c|c|}
\hline \multirow{3}{*}{$\begin{array}{l}\text { Species or } \\
\text { community measure }\end{array}$} & \multicolumn{6}{|c|}{$\begin{array}{c}\text { Without replication } \\
\text { (Kruskal-Wallis One-Way analysis of variance) } \\
\qquad \mathrm{N}=30\end{array}$} & \multicolumn{2}{|c|}{$\begin{array}{l}\text { With replication } \\
\text { (Friedman's test) } \\
\qquad \mathrm{N}=9\end{array}$} \\
\hline & \multicolumn{2}{|c|}{ Forest 1} & \multicolumn{2}{|c|}{ Forest 2} & \multicolumn{2}{|c|}{ Forest 3} & & \\
\hline & $x^{2}$ & $\mathrm{p}$ & $X^{2}$ & $\mathrm{p}$ & $x^{2}$ & $p$ & $x^{2}$ & $\mathrm{p}$ \\
\hline Cychrus caraboides & 1.369 & 0.540 & 0.000 & 1.000 & 2.000 & 0.368 & 0.167 & 0.920 \\
\hline Leistus ferrugineus & 0.557 & 0.757 & 2.887 & 0.236 & 4.573 & 0.102 & 0.500 & 0.779 \\
\hline Notiophilus reiterii & 2.000 & 0.368 & 1.057 & 0.590 & 4.143 & 0.126 & 1.500 & 0.472 \\
\hline Patrobus assimilis & 0.562 & 0.755 & 3.452 & 0.178 & 10.062 & 0.007 & 6.000 & 0.050 \\
\hline Patrobus atrorufus & 2.000 & 0.368 & 2.000 & 0.368 & 1.036 & 0.596 & 0.500 & 0.779 \\
\hline Calathus micropterus & 2.000 & 0.126 & 4.487 & 0.106 & 6.757 & 0.034 & 2.667 & 0.264 \\
\hline Total abundance & 0.438 & 0.803 & 3.779 & 0.150 & 13.132 & 0.001 & 1.167 & 0.558 \\
\hline No. of species (NO) & 0.182 & 0.913 & 2.950 & 0.229 & 11.314 & 0.003 & 1.167 & 0.558 \\
\hline N1 & 0.704 & 0.703 & 8.962 & 0.011 & 3.309 & 0.198 & 2.667 & 0.264 \\
\hline N2 & 2.123 & 0.346 & 9.932 & 0.007 & 3.238 & 0.191 & 4.667 & 0.097 \\
\hline
\end{tabular}




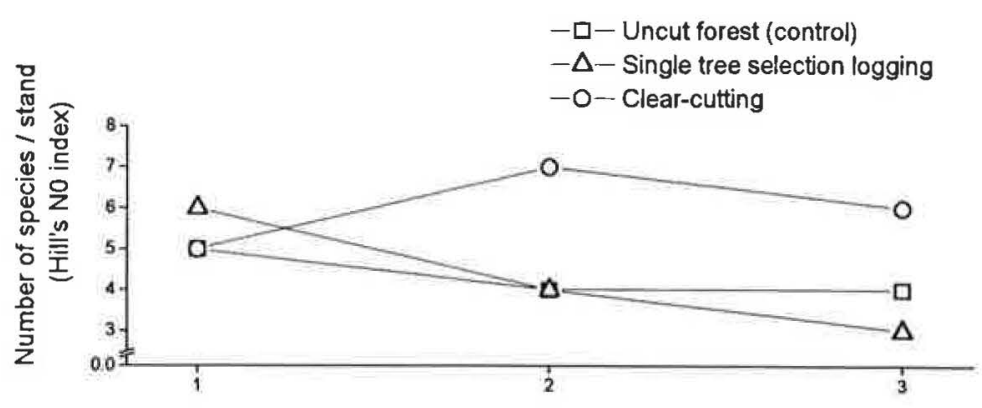

Fig. 2. The three Hill diversity indices for carabid beetles in the three treatments within each forest. The number of species corresponds to Hill's NO index. Hill's $N 1$ index is a measure of the number of very common species, while Hill's N2 index represents the number of common species. Thus, high values of N1 and N2 indicates a dominance of one or a few species. For the number of species each value represents the sum of species found in ten pitfall traps while the N1 and N2 is calculated from the captures in ten traps.
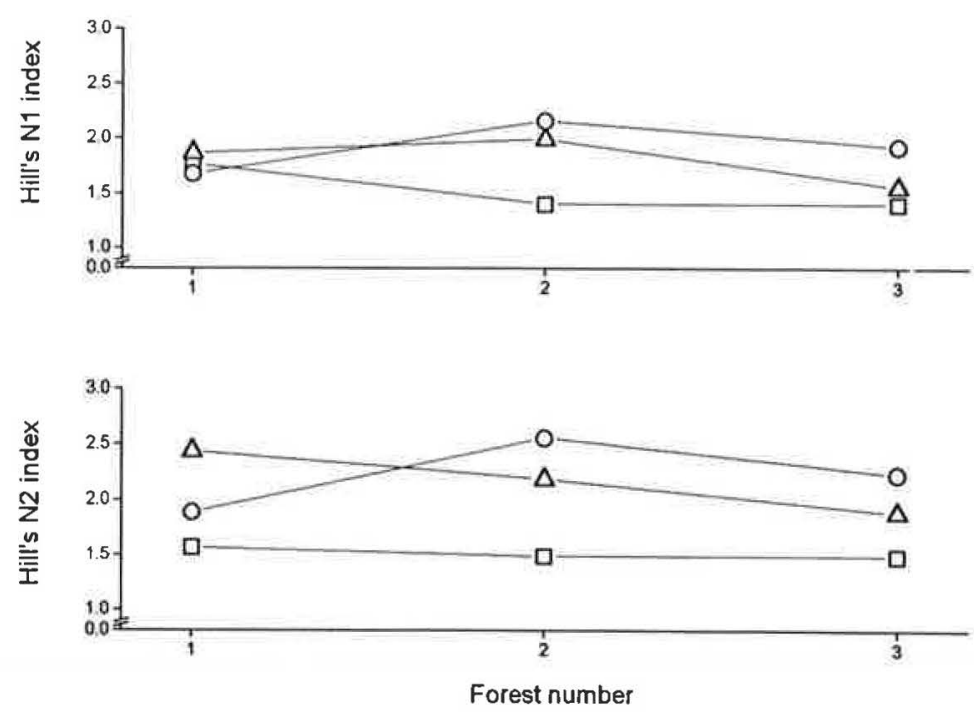

\section{Discussion}

There was a considerable difference in the effects of forest harvest method depending on whether the interpretation was based on results from analysis of any one of the three studied forest areas or a general analysis including all three forests and incorporating site variation (Table 1, last paragraph of Results). Clearly, the data from any one of the studied forest areas (as would be typical for an unreplicated study), would have led to quite different conclusions regarding the effects of the clear cutting and selective logging. For example, if the study was restricted to Forest 1 we would have concluded that there was no treatment effect, while several effects would have been declared significant if Forests 2 or 3 had been chosen (Table 1). It is also noteworthy that none of the forest areas showed the same result as the general analysis and that the overall analysis which incorporates the spatial variation among the sites is not simply the mean of the three.

Ecologists know that "more replication is always better", but the results of our comparison highlight the importance of site replication for the carabid community even with the same given sample size. The divergence of our replicated and nonreplicated analyses suggest that the ground beetle community in the boreal forests of the mountain region of Sweden may be more spatially variable than it might seem, or that the effect of forestry on the carabid community may depend on other unmeasured factors. Thus, our analyses are consistent with Hurlbert's (1984) recommendations that, if possible, (even with the same sampling effort), it is important to employ an experimental design that is robust to potentially-undetected environmental heterogeneity (the same author also provides detailed recommendations of experimental designs when such spatial variation exists). For 
any given sample size, there will always be a tradeoff between replication at a given site and the number of sites. Based on our results, future studies of the ground-dwelling invertebrates in boreal forests should attempt to increase the site replication rather than increase the number of samples from any given forest area. It is hoped that increasing co-operation with forestry companies in experimental logging will permit more such experimental studies with site replication.

Niemelä et al. (1993b) have shown that the responses of the carabid beetle community to clear-cutting is essentially the same in both Canada and Finland, indicating many ecological similarities between the two continents. The authors distinguished three main types of numerical responses: (1) species of open habitats appeared and/ or increased in abundance, (2) there was no dramatic effect on forest generalists, and (3) primary forest specialists disappeared after cutting. Probably as a consequence of (1) and (2), both the abundance and the number of species were higher on clear-cuttings than in primary forests (Niemelä et al. 1993b). In our study, the abundance of $P$. assimilis, a open habitat species (Lindroth 1985), was significantly affected by harvest method (Table 1), and showed increased abundance on the clearcuttings (Fig. 1). This supports the first prediction of Niemelä et al. (1993b). However L.ferrugineus (another open habitat species, Lindroth 1985) was one of the dominant species but was not affected by harvest method. The second prediction of Niemelä et al. (1993b) is also supported because harvest did not affect the abundance of C. micropterus and C. caraboides (Table 1, Fig. 1), which are both forest generalists (Lindroth 1985).

Niemelä et al. (1993b) suggested an increase in the abundance of carabids may be expected on clear-cuttings. However, in our study, there was no overall effect of treatment on carabid abundance (Table $1, \mathrm{p}=0.558$ ). Earlier studies have also shown contradictory results concerning the abundance of carabids following clear-cutting. Lenski (1982) studying oak forests in the U.S., also found mixed results. In pine forests in Czechoslovakia, Sustek (1981) found a decrease in total abundance following clear-cutting while Jennings et al. (1986), studying spruce-fir forest, found greater abundance in dense uncut stands compared with clearcut strips. It appears that the responses of the ground beetle community to tree harvest may be a rather complex phenomenon which may require considerably more study.

In previous studies, species richness increased following clear-cutting (Niemelä et al. 1988, $1993 \mathrm{ab}$ ), probably due to the immigration of open habitat species and moderate effects on forest generalists (see above). Such a pattern was not found in this study (Table 1, Fig. 2). Also, earlier studies have shown an increase in carabid diversity following clear-cutting (Lenski 1982, Jennings et al. 1986, Niemelä et al. 1993ab). However, in our study, there was no significant effect of forest harvest method on Hill's N1 and N2 diversity indices (Table 1, Fig. 2). There was, however, a tendency for the N2 index to be higher in clear-cuts than in uncut controls (Fig. 2), which indicates that the carabid assemblage in clear cuts is dominated by fewer species (here, P. assimilis, $C$. micropterus and L. ferrugineus, Fig. 1). Furthermore, Pterostichus spp., Amara spp. and Harpalus spp. have been reported as rather common in the ground beetle community elsewere (Niemelä et al. 1993b), but these species were not caught in our spring trapping in these Swedish forests. Most previous studies were conducted during longer periods (i.e. the entire snow-free season) whereas ours concentrated on spring. It is thus possible that clear-cutting may have different effects on the carabid community in spring vs summer or fall. Longer term studies in which seasons are evaluated separately are needed to evaluate this possibility (see also Niemelä et al. 1990b).

The results from this study are consistent with earlier reports that clear-cutting increases the abundance of open habitat carabid species while having little or no effect on the abundance of forest generalist species. However, in contrast to previous studies, we found no significant increase in carabid diversity following clear-cutting. As expected, there were no significant differences between the selectively-logged areas and the uncut control forests. Further, for all three diversity indices (Fig. 2) the selective loggings were more similar to the uncut controls than the clear-cuts in two of the three forests studied. This higher concordance between the carabid communities suggests that selective logging in these mountain areas has a lower impact on the original carabid community in spring than does clear-cutting. The 
differences between replicated and unreplicated designs for assessing the effects of forestry highlights the importance of site replication in a spatially-variable system (Hurlbert 1984). This study concentrated on the short-term harvest effects (i.e. 4 years) of the two dominant silviculture practices, but patterns may change as the forest regenerates (see e.g. Niemelä et al. 1993ab). Longer term studies with increased site replication are needed to better evaluate the effects of clear-cutting and selective logging on the ground beetle community in general.

Acknowledgements. We are grateful to Mats Jonsson for assistance in the field, and to Roger Pettersson for taxonomic assistance. The study was financially support by the Faculty of Forestry at the Swedish University of Agricultural Sciences.

\section{References}

Ahti, T., Hämet-Ahti, L. \& Jalas, J. 1968: Vegetation zones and their sections in northwestern Europe. - Ann. Bot. Fennici 5: 169-211.

Ångström, A. 1974: Sveriges klimat. — AB Kartografiska Institutet, Stockholm, Sweden. 188 pp. (In Swedish.)

Bonan, G. B. \& Shugart, H. H. 1989: Environmental factors and ecological processes in boreal forests. - Annu. Rev. Ecol. Syst. 20: 1-28.

Cajander, A. K. 1949: Forest types and their significance. - Acta For. Fenn. 56: 1-71.

Clark, J. S. 1990: Fire and climate changes during the last $750 \mathrm{yrs}$ in northwestern Minnesota. - Ecol. Monogr. 60: $135-159$.

Daniel, T. W., Helms, J. A. \& Baker, F. S. 1979: Principles of silviculture. - 2nd edition, McGraw-Hill Book Company, New York, USA. 500 pp.

Ehnström, B. \& Walden, H. W. 1986: Faunavård i skogsbruket. Den lägre faunan. - Skogsstyrelsen, Jönköping, Sweden. 351pp. (In Swedish.)

Eyre, M. D. \& Luff, M. L. 1990: A preliminary classification of European grassland habitats using Carabid beetles. - In: Stork, N. E. (ed.), The role of ground beetles in ecological and environmental studies. Andover, Hampshire (Intercept): 227-236.

Haila, Y. \& Järvinen, O. 1990: Northern coniferous forests and their bird assemblages. -- In: Keast, A. (ed.), Biogeography and ecology of forest bird communities. SPB Academic Publishing, The Hague, The Netherlands: 61-85.

Hämet-Ahti, L. 1983: Human impact on closed boreal forest (taiga). - In: Holzner, W., Werger, H. J. A. \& Ikusima, I. (eds.), Man's impact on vegetation. W. Junk Publishers, The Hague, The Netherlands: 201-211.
Hansen, A. J., Spies, T. A., Swanson, F. J. \& Ohmann, J. L. 1991: Conserving biodiversity in managed forests: Lessons from natural forests. - BioScience 41: 382-392.

Heliövaara, K. \& Väisänen, R. 1984: Effects of modern forestry on northwestern European forest invertebrates: a synthesis. - Acta For. Fenn. 189: 1-32.

Hurlbert, S. H. 1984. Pseudoreplication and the design of ecological field experiments. - Ecol. Monogr. 54(2): 187-211.

Jarosik, V. 1983: A comparison of the diversity of carabid beetles (Col., Carabidae) of two floodplain forests differently affected by emissions. - Vest. Ceskoslov. Spolec. Zool. 47: 215-220.

Jennings, D. T., Houseweart, M. W. \& Dunn, G. A. 1986: Carabid beetles (Coleoptera: Carabidae) associated with strip clearcut and dense spruce-fir forests of Maine. Coleopt. Bull. 40: 251-263.

Lenski, R. E. 1982: The impact of forest cutting on the diversity of ground beetles (Coleoptera: Carabidae) in southern Appalachians. - Ecol. Entomol. 7: 385-390.

Lindroth, C. H. 1949: Die Fennoskandischen Carabidae. III. Göteborgs Kungliga Vetenskaps och Vitterhetssamhällets Handlingat B4(3): 1-911. (In German.)

Lindroth, C. H. 1985: The Carabidae (Coleoptera) of Fennoscandia and Denmark. - Fauna Ent. Scand. 15: 1-225.

Lindroth, C. H. 1986: The Carabidae (Coleoptera) of Fennoscandia and Denmark. - Fauna Ent. Scand. 15: 233-497.

Loope, W. L. 1991: Interrelationships of fire history, land use history, and landscape pattern within Pictured Rocks National Lakeshore, Michigan. - Canadian FieldNaturalist 105(1): 18-28.

Ludwig, J. A. \& Reynolds, J. F. 1988: Statistical ecology. - John Wiley and Sons, New York, USA. 337 pp.

Luff, M. L. 1990: Spatial and temporal stability of Carabid communities in a grass/arable mosaic. - In: Stork, N. E. (ed.), The role of ground beetles in ecological and environmental studies. Andover, Hampshire (Intercept): 191-200.

Lundberg, S. 1986: Catalogus coleopterorum Sueciac. Entomologiska Föreningen Stockholm, Stockholm, Sweden. 155 pp. (In Swedish.)

Niemelä, J. 1990: Spatial distribution of Carabid beetles in the southern Finnish taiga: the question of scale. - In: Stork, N. E. (ed.), The role of ground beetles in ecological and environmental studies. Andover, Hampshire (Intercept): 143-155.

Niemelä, J., Haila, Y., Halme, E., Lahti, T., Pajunen, T. \& Punttila, P. 1988: The distribution of carabid beetles in fragments of old coniferous taiga and adjacent managed forests. - Ann. Zool. Fennici 25: 107-119

Niemelä, J., Haila, Y., Halme, E., Pajunen, T. \& Punttila, P. 1990a: Diversity variation in carabid assemblages in the southern Finnish taiga. - Pedobiologia 34: 1-10

Niemelä, J., Halme, E. \& Haila, Y. 1990b: Balancing sampling effort in pitfall trapping of carabid beetles. Ent. Fenn. 1: 233-238.

Niemelä, J., Haila, Y., Halme, E., Pajunen, T. \& Punttila, P. 1992: Small-scale heterogeneity in the spatial distribu- 
tion of carabid beetles in the southem Finnish taiga. J. Biogeography 19: 173-181.

Niemelä, J., Langor, D. \& Spence, J. R. 1993a: Effects of clear-cut harvesting on boreal ground-beetle assemblages (Coleoptera: Carabidae) in Westem Canada. Conservation Biology 7: 551-561.

Niemelä, J., Spence, J. R., Langor, D., Haila, Y. \& Tukia, H. 1993b: Logging and boreal ground beetle assemblages on two continents: implications for conservation. - In: Gaston, K. J., New, T. R. \& Samways, M. J. (eds.), Perspectives on insect conservation. Intercept Limited, Andover, Hants, UK.: 29-50.

Punttila, P., Haila, Y., Pajunen, T. \& Tukia, H. 1991: Colonisation of clearcut forests by ants in southern Finnish taiga: A quantitative survey. - Oikos 61: 250-262.

Refseth, D. 1980: Ecological analyses of carabid communities - potential use in biological classification for nature conservation. - Biol. Conserv. 17: 131-141.

Rushton, S. P., Eyre, M. D. \& Luff, M. L. 1990: The effects of management on the occurence of some carabid species in grassland. - In: Stork, N. E. (ed.), The role of ground beetles in ecological and environmental stud- ies. Andover, Hampshire (Intercept): 209-216.

Scudder, G. G. E. 1979: Present pattems in the fauna and flora of Canada. - Mem. Entomol. Soc. Can. 108: 87-179.

Sustek, Z. 1981: Influence of clear cutting on ground beetles (Coleoptera, Carabidae) in a pine forest. - Communicationes Instituti Forestalis Cechoslovaniae 12: 243-254.

Thiele, H-U. 1977: Carabid beetles in their environments. - Springer Verlag, Berlin, Germany. 369 pp.

Tietze, F. 1987: Changes in structure of carabid beetle taxozenosis in grassland affected by intensified management and industrial air pollution. - Acta Phytopath. Entomol. Hung. 22: 305-319.

Tolonen, K. 1983: The post-glacial fire record. - In: Wein, R. W. \& MacLean, D. A. (eds.), The role of fire in northern circumpolar ecosystems. John Wiley and Sons, New York, USA: 21-44.

Zackrisson, O. 1977: Influence of forest fire in the northern Swedish boreal forest. - Oikos 29: 22-32.

Zar, J. H. 1984: Biostatistical analysis. - Prentice-Hall, Inc., Englewood Cliffs, New Jersey, USA. 718 pp. 